\title{
MANAJEMEN PEMBELAJARAN BERBASIS PESANTREN, SEKOLAH DAN MADRASAH
}

\author{
Oleh: Hasmiati $^{1}$ \\ $* * *$
}

\begin{abstract}
Abstrak
Manajemen pembelajaran di sekolah merupakan pengelolaan pada beberapa unit pekerjaan oleh personil yang diberi wewenang, untuk menyukseskan pembelajaran. Sehingga keefektifan manajemen pembelajaran dapat dicapai manakala fungsi perencanaan, pengorganisasian, penggerakan dan pengawasan dapat diimplimentasikan dengan baik dan benar dalam program pembelajaran. Agar mutu pembelajaran di lembaga pendidikan baik sekolah, maupun madrasah, dapat dikelolah dengan baik, maka ada beberapa langkah yang harus dilaksanakan oleh para pelaku di lembaga pendidikan tersebut, dengan mengimplementasikan Fungsi manajemen pembelajaran yaitu perencanaan pengajaran, pengorganisasian pembelajaran, pelaksanaan pembelajaran dan evaluasi pembelajaran. Dalam menjalankan fungsi manajemen pembelajaran seorang guru harus memanfaatkan sumber daya pengajaran yang ada dalam kelas maupun yang ada di luar kelas. Peran guru sebagai manajer melakukan pembelajaran adalah proses mengarahkan peserta didik untuk melakukan kegiatan belajar dalam rangka perubahan tingkah laku, (kognitif, afektif, psikomotorik) menuju kedewasaan.
\end{abstract}

Oleh karena itu agar proses belajar mengajar yang dilakukan berjalan lancar dan dapat menciptakan iklim yang kondusif dimana peserta didik merasa nyaman dan tidak tertekan dalam menerima pelajaran, maka dibutuhkan manajemen dalam mengelola pembelajaran tersebut. Manajemen pembelajaran selain diawali dengan dengan perencanaan yang baik, serta didukung komunikasi yang baik, juga harus didukung pengembangan strategis yang mampu membelajarkan siswa. Karena manajemen pembelajaran, merupakan suatu proses penyelenggaraan intraksi peserta didik, pendidikk dan sumber pada suatu lingkungan belajar.

Kata Kunci: Manajemen Pembelajaran, Pesantren, Sekolah Dan Madrasah

\footnotetext{
${ }^{1}$ Dosen pada STAI Muhammadiyah Sinjai
} 


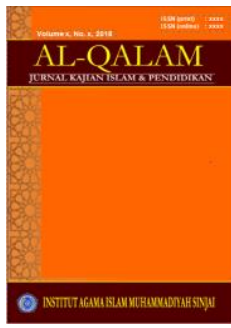

\section{PENDAHULUAN}

$\mathrm{U}$

paya memperbaiki dan meningkatkan mutu pendidikan seakan-akan tidak pernah berhenti. Pembaharuan dalam bidang pendidikan merupakan suatu karakter. Hal tersebut pada dasarnya berkisar pada pada persepsi bahwa pendidikan merupakan menara gading bahkan pelopor pembaruan. Segi kognitif pendidikan tetap mendapatkan prioritas yang tinggi dalam proses pendidikan, namaun masalah integrasi proses dan hasil belajar dengan kehidupan yang nyata dan masa depan semakinmeminta penekanan-penekanan baru. Khususnya kurikulum pendidikan dalam hal ini proses pembelajaran, seyogyanya dirancang untuk memberikan pengalaman-pengalaman yang merangsang peningkatan kreativitas, intelektual, dan daya analisis.

Pendidik adalah agen perubahan, merekalah yang membuat peradaban dunia berubah menjadi lebih baik, penerang dalam kegelapan, penunjuk arah generasi. Pada merekalah pemin[in belajar bersikap bijaksana. Karenanya pendidik tidak boleh salah ajar. Semua tindakan mereka harus terencana dan terukur dengan baik. Aktivitas utama seorang guru di Pesantren, Sekolah dan Madrasah adalah melaksanakan pembelajaran. Proses pembelajaran sangat terkait dengan berbagai komponen tersebut dapat dimanfaatkan secara optimal. Hal terebut akan terwujud manakala seorang pendidik memiliki sebagai desaigner pembelajaran memiliki kompetensi manajemen pembelajaran.

\section{PEMBAHASAN}

\section{A. Pengertian Manajemen Pembelajaran}

Mengkaji mengenai pembelajaran maka kita akan dihadapkan pada sebuah aspek penting yang sering kita sebut dengan istilah manajemen Pembelajaran, maka terlebih dahulu kita akan menguraikan pengertian manajemen dan pembelajaran itu sendiri. Kata manajemen berasal dari kta bahasa latin, yaitu asal kata manus yang berarti tangan dan agere yang berarti melakukan. Kata itu digabungkan menjadi managere yang berarti menangani managere diterjemahkan dalam bahasa Inggris dalam bentuk kata kerja to manage, dengan kata benda management, dan menager untuk orang yang melakukan kegiatan dengan manajemen. Akhirnya managemen 


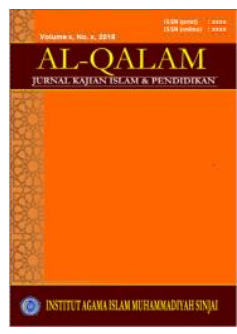

diterjemahkan da;lam bahasa Indonesia menjadi manajemen atau pengelolaan. $^{2}$

Secara istilah managemen mengandung pengertian suatu proses pencapaian tujuan organisasi lewat usaha orang lain. ${ }^{3}$ Manajemen merupakan proses pendayagunaan bahan baku dan sumber daya manusia untuk mencapai tujuan yang telah ditetapkan. Proses ini melibatkan organisasi, esensi manajemen adalah efektivitas bekerja melalaui orang lain untuk meraih berbagai hasil. Melalui manajemen dilskukan proses pengintegrasian berbagai sumber daya dan tugas untuk mencapai berbagai tujuan organisasi. ${ }^{4}$

Pembelajaran adalah perpaduan dua aktivitas mengajar dan belajar. Sebelum menjelaskan tentang pembelajaran terlebih dahulu akan dijelaskan pengertian belajar dan mengajar. Konsep tentang belajar merupakan satu rangkaian dengan konsep lain disebut mengajar. Mengajar dan belajar merupakan dua konsep yang berbeda. Menurut Skinner belajar merupakan perubahan tingka laku yang bertahap dari bentuk sederhana sampai kebentuk yang kompleks.

Sedangkan mengajar adalah suatu aktivitas yang mentransfer pengetahuanatau keterampilan dari satu pihak ke piahak lain. ${ }^{5}$ Mengajar adalah membina siswa bagaimana belajar, berfikir dan menyelidiki. Dalam mengajar proses yang terjadi pada guru sedang dalam belajar proses yang terjadi pada siswa. Sementara pembelajaran adalah usaha yang dilakukan oleh seorang untuk mempengaruhi pihak lain agar melakukan aktivitas belajar dengan kata lain pembelajaran merupakan proses interaksi yang terjalin antara siswa dan guru dalam sekolah di lingkungan yang telah dikondisikan sebelumnya. ${ }^{6}$

2 Husaini Usman, Managemen Teori, Praktik dan Riset Pendidikan, (Jakarta: Bumi Aksara,2006), hlm.3.

3 Miftah Toha, Perilaku Organisasi, Konsep Dasar dan Aplikasi, Jakarta: Raja Grafindo, 2006), hml. 260.

${ }^{4}$ Henri Simamora, Manajemen Sumber Daya Manusia, (Yogyakarta: Bagian Penerbitan STIE YKPN, 2004), hlm. 4.

5 Suharsimi Arikunto, Pengelolaan Kelas dan Siswa Sebuah Pendekatan Evaluative, (Jakarta: Raja Grafindo Persada, 1996), hal. 19.

6 Tohirin, Psikologi Pembelajaran Pendidikan Agama Islam Berbasis Integrasi dan Kompetisi, (Jakarta: Raja Grafindo Persada, 2000), hal. 8. 
Istilah pembelajaran dipergunakan untuk menunjukkan konteks yang menekankan pada pola intruksi guru dan murid atau interaksi antara kegiatan mengajar dan belajar. Hal ini berarti bahwa pembelajaran memiliki pengertian yang didalamnya mencakup sekaligus proses mengajar yang berisi serangkaian perbuatan guru untuk menciptakan situasi kelas dan proses belajar yang terjadi padasiswa yang berisi perbuatan-perbuatan murid untuk menghasilkan perubahan pada diri siswa sebagai akibat dari kegiatan belajar mrngajar, pembelajaran yang dimaksud sebagai penciptaan suasana sehingga siswa belajar.

Wina Sanjaya kata pembelajaran adalah terjemahan dari kata intruction yang banyak dipakai dalam dunia pendidikan, istilah ini dipengaruhi oleh filsafat kognitif holistik, yang menempatkan siswa sebagai sumber dari kegiatan. Selain itu istilah ini juga dipengaruhiboleh perkembangan teknologi yang diasumsikan dapat mempermudah siswa mempelajari segala sesuatu lewat berbagai media, seperti bahan cetak, gambar, audio sehingga semua itu mendorong terjadinya perubahan peranan guru dalam mngelolah proses belajar mengajar, dari guru sebagi sumber fasilitator dalam belajar mengajar. ${ }^{7}$

Senada yang diungkapkan Corey yang dikutip oleh Syarifuddin Sagala bahwa pembelajaran adalah suatu proses dimana lingkungan seseotrang secara sengaja dikelolah untuk memungkinkan ia turut serta dalam tingka laku tertentu dalam kondisi khusus atau menghasilkan kesan terhadap situasi tertentu, pembelajaran merupakan subsistem khusus dari pendidikan. ${ }^{8}$

Dalam UU. No. 20 tahun 2003 tentang sistem Pendidikan Nasional, istilah pembelajaran telah mencakup istilah mengajar dan belajar. ${ }^{9}$ Pengertian dalam undang-undang tersebut berarti proses interaksi peserta didik dengan pendidik dengans sumber belajar pada suatu lingkungan belajar. Aplikasi pembelajaran dunia pendidikan dapat dibuktikan dengan beberapa tindakan guru sebagai berikut:

7 Wina Sanjaya, Strategi Pembelajaran, (Jakarta: Kencana, 2006), hlm. 104.

8 Syaiful Sagala, Konsep dan makna Pembelajaran; untuk membentuk, memecahkan problematika belajar dan mengajar, (Bandung: Alfabeta, 2009), hlm. 61

9 UU SIKDIKNAS, Peraturan dan Pelaksanaannya, (Jakarta: Sinar Grafika, 1991), hlm. 34. 


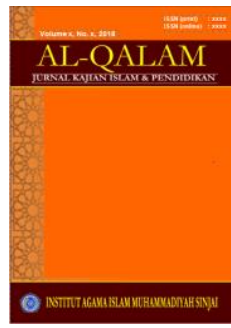

1. Guru dapat membimbing segala aktivitas yang dilakukan siswa yang mendukung tercapainnya tujuan materi pembelajaran

2. Guru harus dapat membimbing pengalaman anak, yaitu intraksi anak dengan lingkungannya dalam intraksi itulah siswa dapat memproses pengertian sikap, penghargaan, kebiasaan dan kecakapan.

3. Guru dapat membantu anak berkembang dan menyesuaikan diri di lingkungannya . materi pembelajaran tidak semata-mata ditunjukkan kepada evaluasi dan ujian saja.

\section{B. Pengelolaan Pembelajaran}

Pada dasarnya guru adalah seorang pendidik. Pendidik adalah orang dewasa dengan segala kemampuan yang dimilikinya untuk dapat mengubah psikis dan pola pikir anak didiknya dari tidak tahu menjadi tahu serta mendewasakan anak didiknya. Salah satu hal yang harus dilakukan oleh seorang guru adalah mengajar dikelas.

Dalam proses pembelajaran dikenal beberapa istilah yang dimiliki kemiripan makna sehingga sering kali orang bingung untuk membedakannya. Istilah tersebut (1) pendekatan pembelajaran (2) strategi pembelajaran, (3) metode pembelajaran, (4) teknik pembelajaran (5) taktik pembelajaran dan (6) model pembelajaran. Berikut ini akan dipaparkan istilah tersebut dengan harapan dapat memberikan kejelasan tentang penggunaan istilah tersebut.

Pendekatan Pembelajaran dapat diartikan sebagai titik tolak atau sudut pandang kita terhadap proses pembelajaran, yang merujuk pada pandangan tentang terjadinya susatu proses yang sifatnya masih sangat umum. Didlamnya mewadahi, menginspirasi, menguatkan, dan melatari metode pembelajaran dengan cakupan teoritis tertentu. Dilihat dari pendekatannya pembelajaran terdapat dua jenis pendekatan, yaitu; 1 Pendekatan Pembelajaran yang berorientasi atau pusat pada siswa (student centered approach). (2) strategi pembelajaran, yang berorientasi atau pusat pada guru (teacher centered approach).dari pendekatan pembelajaran yang telah ditetapkan selanjutnya diturunkan ke dalam strategi pembelajaran, mengemukakan empat strategi dari setiap usaha, yaitu : 


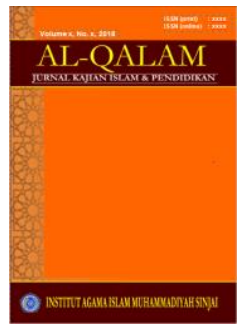

1. Mengidentisifaksi dan menetapkan spesifikasi dan kualifikasi hasil (out put) dan sasaran ( target) yang harus dicapai dengan mempertimbangkan aspirasi dan selera masyarakat yang memerlukannya.

2. Mempertimbangkan dan memilihbjalan pendekatan utama (basic way) yang paling efektif untuk mencapai sasaran.

3. Mempertimbangkan dan nenetapkan langkah-langkah (steps) yang akan ditempuh sejak titik awal sampai dengan sasaran.

4. Mempertimbangkan dan menetapkan tolok ukur (criteria) dan patokan ukuran ( standard) untuk mengukur dan menilai taraf keberhasilan (achievement) usaha.

Jika diterapkan dalam konteks pembelajaran , keempat unsure tersebut adalah:

1. Menetapkan spesifikasi dan kualifikasi tujuan pembelajaran yakni perubahan profil perilaku dan pribadi peserta didik.

2. Mempertimbangkan dan memilih sistem pendekatan pembelajaran yang dipandang paling efektik.

3. Mempertimbangkan dan menetapkan langkah-langkah atau prosedur, metode dan teknik pembelajaran.

4. Menetapkan norma-norma dan batas minimum ukuran keberhasilanatau criteria dan ukuran keberhasilan atau kriteria dan ukuran baku keberhasilan.

Sementara itu, KEMP yang dikutip oleh Wina Sanjaya, mengemukakan bahwa strategi pembelajaran adalah suatu kegiatan pembelajaran yang harus dikerjakan guru dan siswa agar tujuan pembelajaran dapat dicapai secara efektif dan efisien. ${ }^{10}$ Metode pembelajaran dapat diartikan sebagai cara yang digunakan untuk mengiplementasikan rencana yangsudah disusun dalam bentuk kegiatan nyata dan praktis untuk mencapai tujuan pembelajaran. Terdapat beberapa metode pembelajaran yang dapat digunakan dalam mengimplementasikan strategi pembelajaran, diantarannya: (1) ceramah (2) demonstrasi (3) diskusi (4) simulasi (5) laboratorium (6) pengalaman (7) brainstorming (8) debat (9) symposium, dan sebagainya. Teknik pembelajaran adalah cara yang dilakukan seseorang untuk mengiplementasikan metode secara spesifik. misalnya, penggunaan metode ceramah pada kelas dengan jumlah siswa yang relatif banyak membutuhkan teknik tersendiri. Yang tentunya secara teknis

10 Wina Sanjaya, Strategi Pembelajaran Berorientasi Standar Proses Pendidikan, (Jakarta: Kencana, 2011), hlm. 126. 


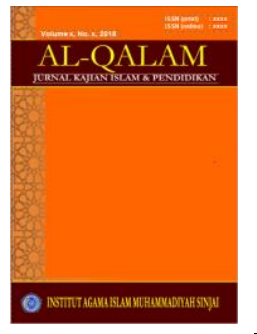

akan berbeda dengan penggunaan metode ceramah pada jumlah siswayang terbatas. Dengan demikian, penggunaan metode diskusi perlu digunakan teknik yang berbeda pada kelas yang siswanya tergolong aktif dengan kelas yang tergolong pasif. Dalam hal ini, guru pun daatberganti-ganti teknik meskipun dalam koridor metode yang sama.

Taktik pembelajaran merupakan gaya seseorang dalam melaksanakan metode atau teknik pembelajaran tertentu yang sifatnya individual. misalkan terdapat dua orang sama-sama menggunakan metode ceramah tetapi mungkin berbeda dengan taktik yang digunakannya. dalam penyajiannya yang satu yang cenderung banyak diselingi humor karena memang dia memiliki sense of humor yang tinggi tetapi yang satunya kurang memiliki sense humor tetapi menggunakan alat eletronik karena memang dia memiki keahlian menggunakan alat itu. dalam gaya pembelajaran akn tampak keunikan masing-masing guru. sesaidengan kemampuan, pengalaman dan tipe kepribadian dari guru yang bersangkutan. dalam taktik ini, pembelajaran akan menjadi sebuah ilmu sekaligus juga seni (kiat). Model pembelajaran merupakan rangkaian antara pendekatan, metode, taktik strategi, teknik bahkan taktik pembelajaran sudah utuh yang terbentuk. Jadi, model pembelajaran pada dasarnya merupakan bentuk pembelajaran yang disajikan dari awal hingga akhir oleh guru secara khas dan unik. Dengan kata lain, model pembelajaran merupkan bungkusan atau bingkai penerapan suatu pendekatan, metode, dan teknik pembelajaran.

Berdasarkan uraian di atas, bahwa untuk dapat melaksanakan tugasnya secara professional, seorang guru dituntut dapat memahami dan memiliki keterampilan yang memadai dalam mengembangkan berbagai model pembelajaran yang efektif, kreatif dan menyenangkan.

\section{Fungsi-Fungsi Manajemen Pembelajaran}

Manajemen pembelajaran di sekolah merupakan pengelolaan pada beberapa unit pekerjaan oleh personil yang diberi wewenang, untuk menyukseskan pembelajaran. Sehingga keefektifan manajemen pembelajaran dapat dicapai manakala fungsi perencanaan, pengorganisasian, penggerakan dan pengawasan dapat diimplimentasikan dengan baik dan benar dalam program pembelajaran. Fungsi manajemen pembelajaran merupakan perencanaan pengajaran, pengorganisasian pembelajaran, pelaksanaan pembelajaran dan evaluasi pembelajaran. 


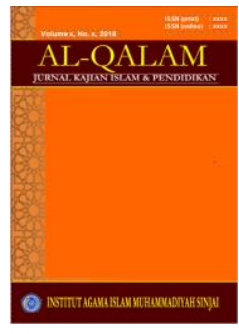

AL-QALAM

Jurnal Kajian Islam \& Pendidikan

Volume 06 No 012014

ISSN (print) : 1858-4152

ISSN (online) : -

Homepage : http://journal.iaimsinjai.ac.id/index.php/al-qalam

Dalam menjalankan fungsi manajemen pembelajaran seorang guru harus memanfaatkan sumber daya pengajaran yang ada dalam kelas maupun yang ada di luar kelas. Peran guru sebagai manajer melakukan pembelajaran adalah proses mengarahkan peserta didik untuk melakukan kegiatan belajar dalam rangka perubahan tingkah laku, (kognitif, afektif, psikomotorik) menuju kedewasaan. Menurut Syarifuddin dan Irwan Nasution, bahwa peran guru sebagai manajer dalam proses pembelajaran adalah: ${ }^{11}$

1. Perencanaan Pembelajaran

Perencanaan Pembelajaran merupakan pekerjaan yang dilakukan oleh seorang guru untuk merumuskan tujuan. ${ }^{12}$ Ada beberapa alasan mengapa guruguru merencanakan pembelajaran, 1) perencanaan dapat mengurangi kecemasan dan tidak kepastian. 2) perencanaan memberikan pengalaman bagi guru, 3) perencanaan membolehkan para guru mengakomodasi perbedaan individu diantara murid, 4) perencanaan memberikan struktur dan arah untuk pelajaran. Dalam kedudukannya seorang manajer guru merencanakan, yaitu menyusun tujuan belajar mengajar atau melakukan perencanaan pembelajaran yang mencakup usaha untuk 1) menganalisis tugas, 2) mengidentifikasi kebutuhan pelatihan atau belajar, dan 3) menulis laporan belajar.

2. Pengorganisasian Pembelajaran

Menurut Handoko sebagaimana yang dikutip oleh Usaini Usman pengorganisasian adalah: ${ }^{13}$

a) Penentuan sumber daya dan kegiatan yang dibutuhkan untuk mencapai tujuan organisasi.

b) Proses perancangan dan pengembangan suatu organisasi yang akan dapat membawa hal-hal tersebut kearah tujuan.

c) Penugasan tanggungjawab tertentu.

d) Pendelegasian wewenang yang diperlukan kepada individu-individu untuk melakukan tugas tugasnya.

11 Safruddin dan Irwan Nasution, Manajemen Pembelajaran, (Jakarta: Quantum Teaching, 2005), hlm. 75 .

12 Ibid, hlm 94.

13 Husaini Usman, Manajemn : Teori, Praktik dan Riset Pendidikan, (Jakarta: Bumi Aksara, 2006), hlm. 127. 


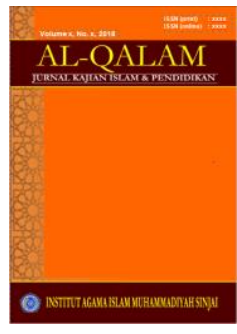

AL-QALAM

Jurnal Kajian Islam \& Pendidikan

Volume 06 No 012014

ISSN (print) : 1858-4152

ISSN (online) : -

Homepage : http://journal.iaimsinjai.ac.id/index.php/al-qalam

Maka pengorganisasian itu merupakan adanya penyusunan struktur organisasi untuk saling bekerja sama yang sesuai dengan tujuan organisasi, sumber daya yang dimilikinya, dan lingkungannya. Mengorganisasikan yaitu menghubungkan atau menggabungkan seluruh sumber daya yang belajar mengajar dalam mencapai tujuan secara efektif dan efisien. Hal yang penting untuk diperhatikan dalam pengorganisasian adalah bahwa setiap kegiatan harus jelas siapa yang mengerjakan, apa yang dikerjakan, dan aap target sehingga tercapai tujuan bersama. ${ }^{14}$

3. Pelaksanaan pembelajaran

Pelaksanaan pembelajaran merupakan tindak lanjut dari proses perencanaan pembelajaran dan pengorganisasian. Disinilah guru memiliki kewajiban untuk melaksanakan apa yang telah direncanakan sebelumnya, sehingga guru memiliki wewenang untuk menyampaikan materi yang telah disusun dengan menggunakan metode dan bantuan media pembelajaran yang telah diprsiapkan sebelumnya dan memotivasi peserta didik untuk siap menerima materi pendidikan.

Pelaksanaan pembelajaran membutuhkan media pembelajaran yang bertujuan membantu memudahkan guru dalam menyampaikan materi pembelajaransesuai dengan kebutuhan siswa itu sendiri. Namun yang perlu diperhatikan dalam penggunaan media adalah disesuaikan dengan media pembelajaran yang aman berorientasi pada segu kognitif, segi afektif, maupun psikomotorik. Dalam tahapan prosedur mengajar ada berbagai hal yang perlu dikuasai oleh pengajar yang bermutu yakni kemampua dalam :

a. Menggunakan media/alat.

b. Berkomunikasi dengan siswa.

c. Mendemonstrasikan khasana metode mengajar.

d. Mendorong keterlibatan siswa dalam pembelajaran.

e. Mendemonstrasikan penguasaan mata pelajaran.

f. Mengorganisasikan waktu, ruang, dan perlengkapan pengajar.

g. Melaksanakan evaluasi pencapaian mahasiswa dalam proses mengajar.

Dalam pelaksanaan proses pembelajaran perlu diperhatikan langkahlangkah sebagaiman berikut ini;

${ }_{14}$ M. Manulang, Dasar-Dasar Manajemen, (Yogyakarta: Gadja Mada University Press, 2009), hlm. 99. 


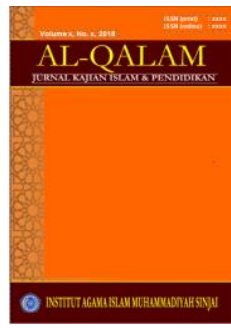

AL-QALAM

Jurnal Kajian Islam \& Pendidikan

Volume 06 No 012014

ISSN (print) : 1858-4152

ISSN (online) : -

Homepage : http://journal.iaimsinjai.ac.id/index.php/al-qalam

1) Tahap memulai pelajaran

Tahap memulai pembelajaran peran guru sangat menentukan keberhasilan peserta didik, maka dari itu dalam memulai pelajaran guru harus melahirkan motivasi dan apersepsi yang relevan dengan materimateri pelajaran yang relevan dengan materi pelajaran yang akan dibahas. Karena motivasi merupakan keinginan yang terdapat pada seorang individu yang meransang untuk melakukan setiap tindakan - tindakan atau sesuatu yang kan menjadi alasan seseorang untuk berprilaku, baik itu prilaku yang sifatnya instrinstik maupun sifatnya ekstrinsik.

Dalam konsep pembelajarn motivasi berarti seni mendorong peserta didik untuk terdorong melakukan kegiatan belajar sehingga tujuan pembelajaran tercapai, untuk itu maka guru harus berupaya menimbulkan dan mempertahankan perhatian dan dorongan peserta didik untuk melakukan kegiatan belajara.

2) Tahap penyampaian materi pembelajaran

Penyampaian dan penjelasan materi pembelajaran merupakan bagian yang urgen dari proses pembelajaran karena penjelasan guru dan penyampaian materi akan berpengaruh terhadap peningkatan pemahaman peserta didik. maka dari itu, guru menyampaiakan materi pembelajaran perlu benar-benar menguasai materi yang akan disampaikan. Oleh karena itu, guru dalam menyampaiakan materi harus memperhatikan antara lain; isi materi harus benar, menggunakan bahasa yang benar, sehingga mudah dipahami peserta didik, penyampaian materi yang disampaikan menekankan pada bagian-bagian materi yang penting lancar dan sistematis.

3) Tahap penggunaan alat pembelajaran

Pemanfaatan atau penggunaan alat pembelajaran secara tepat dan cepat dalam proses pembelajaran dapat menimbulkan kesan yang mendalam pada diri peserta didik melakukan dan mengamati terjadinya proses pembelajaran yang efektif dan efisien. Bahwa efektif dan efisien proses pembelajaran manakala alat yang dipergunakan membantu peserta didik memahami materi pelajaran yang diajarkan. 


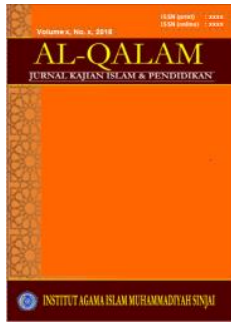

AL-QALAM

Jurnal Kajian Islam \& Pendidikan

Volume 06 No 012014

ISSN (print) : 1858-4152

ISSN (online) : -

Homepage : http://journal.iaimsinjai.ac.id/index.php/al-qalam

4) Tahap penggunaan metode pembelajaran yang tepat

Untuk menunjang peserta didik maka guru penting menggunakan metode pembelajaran yang baik dan tepat guna demi menghantarkan keberhasilan peserta didik dalam pembelajaran. Oleh kaerna itu, proses pembelajaran guru benar-benar menggunakan metode sesuai materi yang diajarkan dan mampu mengaktifkan peserta didik.

Dalam proses pembelajaran, peserta dalam menggunakan atau memilih metode pembelajaran sebaiknya. Memperhatikan hal-hal berikut; tujuan pendidikan, kemampuan pendidik, kebutuhan peserta didik, isi materi pembelajaran. ${ }^{15}$ Berate uapaya peningkatan kualitas pembelajaran tidak hanya pada persiapan yang matan dan tepat, namun ditentukan juga pada kualitas proses yang berkaitan dengan penggunaan metode yang tepat dan bervariasi.

5) Tahap pengelolaan kelas yang tepat

Upaya guru dalam mengelolah kelas yang merupakan faktor pendukung falm proses pembelajaran yang efektif serta dapat membentuk tercapainya belajar secara optimal, menurut Arikunto yang dikutip oleh Syafaruddin, bahwa pengolaan kelas adalah suatu usaha yang dilakukan oleh guru dalam membantu murid sehingga dapat dicapai kondisi yang optimal pelaksanaan kegiatan belajar mengajar seperti yang diharapkan. ${ }^{16}$ adapun tujuan pengelolaan kelas adalah agar setiap peserta didik dikelas dapat bekerja dengan tertib sehingga tercapai tujuan pembelajaran yang efektif dan efisien.

6) Evaluasi

Salah satu peran penting dalam pembelajaran adalah pemahaman terhadap evaluasi dan aplikasi dalam peningkatan mutu. Maka salah satu kompetensi yang harus dikuasi oleh seorang guru dalam menguasai evaluasi pembelajaran termasuk didi dalamnya melaksanakan penilaian proses dan hasil belajar. Karena evaluasi proses belajar dan hasil belajar pada hakikatnya merupakan suatu kegiatan untuk mengukur perubahan perilaku yang telah terjadi. Dalam melakukan evaluasi pembelajaran amat dianjurkan untuk guru lebih mengutamakan teks tertulis, jadi peserta didik

15 Suwardi, Manajemen Pembelajaran; Menciptakan Guru Kreatif dan Berkompetensi, (Jogjakarta: STAIN Salatiga Press, 2007), hlm. 62.

16 Syarifuddin dan Irwan Nasution, Manajemen......., hlm. 118. 


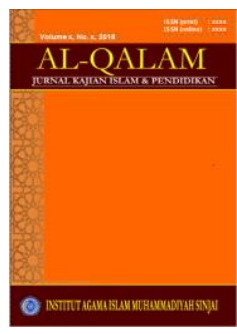

AL-QALAM

Jurnal Kajian Islam \& Pendidikan

Volume 06 No 012014

ISSN (print) : 1858-4152

ISSN (online) : -

Homepage : http://journal.iaimsinjai.ac.id/index.php/al-qalam

diamati melalui tingkah laku. Cara ia bergaul, bagaimana mereka bersosialisasi di masyarakat dan bagaimana mereka menerapkan pembelajaran di kelas dalam kehidupan sehari-hari.

Oleh karena itu, untuk merancang evaluasi itu merupakan tugas guru ketika membuat rancangan pembelajaranuntuk mengetahui hasil pembelajaran. Hamalik mengemukakan bahwa evaluasi adalah keseluruhan kegiatan pengukuran (pengumpulan data dan informasi), pengolahan, penafsiran, dan pertimbangan untuk membuat keputusan tentang tingkat hasil belajar yang dicapai peserta didik setelah melakukan kegiatan belajar mengajar dalam upaya mencapai tujuan pembelajaran. ${ }^{17}$

Sedangkan pengertian evaluasi pembelajaran atau kegiatan yang sistematis, berkelanjutan, dan menyeluruh dalam rangka pengendalian, penjaminan dan penetapan kualitas (nilai dan arti) pembelajaran terhadap berbagai komponen pembelajaran berdasarkan pertimbangan dan kriteria tertentu sebagai bentuk pertanggung jawaban guru dalam melaksanakan pembelajaran. $^{18}$

Artinya bahwa guna menutup serangkaian proses kegiatan pembelajaran yang telah berlangsung maka guru melakukan proses evaluasi atau penilaian kelas yang bertujuan untuk mengetahui sejauh mana kemampuan peserta didik dalam memahami materi yang telah diajarkan sebagaiman lazimnya bahwa evaluasi pembejaran itu adalah tahap paling akhir dari tahap manajemn pembelajaran yang dilakukan untuk menjamin bahwa tujuan telah dicapai berdasrkan perencanaan yangbtelah ditetapkan . di samping itu evaluasi dimaksudkan untuk melihat kembali hal-hal yang sekiranya ada yang belum dilaksanakan dalam proses pembelajaran baik dari segi penggunaan metode, materi, penguasaan kelas.

Penilaian otentik (penilaian kelas) tersebut mencakup pree test.evaluasi proses dan post tes. Ketia tersebut dijelaskan sebagaimana berikut ini:

17 E. Mulyasa, Implementasi Kurikulum 2004 Panduan Pembelajaran KBK, (Bandung: Remaja Rosda Karya, 2004), hlm. 170.

18 zainal Arifin, Evaluasi Pembelajaran: Prinsip Teknik, Prosedur, (Bandung: Remaja Rosda Karya, 2009), hlm. 9. 
1. Pre test (tes awal) merupakan kegiatan awal dari pelaksanaan pembelajaran yang dilakukan alam waktu singkat misalnya 1 menit sampai 5 menit yakni untuk mengukur kemampuan yang dimiliki peserta didik dengan mempelajari bahan ajar dengan mengingat kembali materi sebelumnya. Pre tes dapat dilakukan agar guru dapat mengetahui tingkat pengetahuan, kemampuan, dan pengalaman peserta didik. Oleh karena itu, dengan mengetahui kemampuan awal dan karakteristik peserta didik maka akan memberikan kemudahan guru dalam menyampaikan materi pembelajaran dengan demikian pre tes memegang peranan penting dalam proses pembelajaran.

2. Evaluasi proses kualitas pembelajaran dapat melihat dari segi proses, pembelajaran dikatakan berhasil dan berkualitas manakala seluruhnya atau sebagian besar pesert a didik terlihat secara aktif, baik fisik, mental, maupun sosial dalam proses pembelajaran.sementara dari segi lain, proses pembelajaran dikatakan berhasil manakalah terjadi perubahan perilaku positifnya pada peserta didik.

3. Post tes merupakan tahap akhir dari pelaksanaan pembelajaran, dalam tahap ini guru menyimpulkan dari materi yang telah diajarkan dan dipelajari peserta didik. Selain itu, post tes digunakan untuk mengetahui efektifitas strategis pembelajaran dan pembentukan kopetensi.

\section{Manajemen Pembelajaran di Pondok Pesantren, Sekolah dan Madrasah}

1. Manjemen pembelajaran dipondok pesantren

Sistem pendidikan di pesantren juga atas terdiri atas unsure-unsur dan nilai yang merupakan suatu kesatuan. Dan kualitas dari dinamika suatu pesentren tergantung pada kualitas pada pengasuhnya dan bobot instransi antar unsur dan pelaku pesantren yang ada. Hampir dapat dipastikan lahirnya sebuah pesanter didalamnya, ada lima elemen pesantren satu dengan lainnya tidak pisah dipisahkan. ${ }^{19}$

Kelima elemen tersebut meliputi:

a) Kyai

Kyai atau pengasuh podok pesantren merupakan elemen yang sangat esensial bagi suatu pesantren. Rata-rata pesantren yang berkembang di Jawa dan Madura, sosok kyai sangat berpengaruh,

19 Amin Haedarai, dkk. Masa Depan Pesantren: dalam Tantangan Modernitas dan Tantangan Koplksitas Global, (Jakarta: IRD Press Jakarta, 2004). 


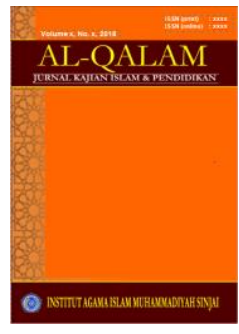

karismatik dan berwibawa, sehingga amat disegani masyarakat. Istilah kyai ini biasanya lazim digunakan di Jawa Tengah dan Jawa Timur, sementara di Jawa Barat dikenal dengan istilah ajengan di Aceh disebut Tengku, sedangkang di Sumatra Barat di sebut buya.

b) Pondok

Pondok atau tempat tinggal para santri merupakan cirri khas tradisi pesantren yang membedakannya dengan sistem pendidikan lainnya yang berkembang dikebanyakan wilayah Islam di Negaranegara lain.

c) Masjid

Seorang kyai yang mengembbangkan pesantren pda umumnya yang pertama-tama menjadi prioritas adalah Masjid. Masjid dianggap sebagai simbol yang tidak terpisahkan dari pesantren. Masjid tidak hanya berfungsi sebagai tempat ritual ibadah tetapi juga tempat pengajaran kitab-kitab.

d) Santri

Santri adalah siswa atau murid yang belajar di pesantren. Seorang ulama biasa disebut kyai kalau memiliki pesantren dan santri yang tinggal dalam pesantren tersebut memiliki ilmu-ilmu agama Islam melalui kitab kuning. Oleh karena Itu, eksistensi biasanya juga berakaitan dengan adanya santri di pesantrennya.

e) Mengajar kitab

Berdasrkan catatan sejarah pesantren telah mengajarkan kitab-kitab klasik, mengajarkan kitab-kitab kuning berbahasa Arab tanpa harakat atau sering disebut kitab gundul. Merupakan metode yangsecara formal yang diajarkan dalam komunitas pesantren di Indonesia.

Pasantren sebagai tempat pendidikan agama memiliki basis sosial yang jelas, karena keberadaannya menyatu dengan masyarakat. Visi ini menuntut adanya perandan fungsi pondok pesantren yang sejalan dengan kondisi masyarakat, bangsa dan Negara yang trus berkembang. Sementra itu, sebagai suatu komunitas pesantren dapat berperan menjadi penggerak bagi upaya peningkatan kesejahteraan masyarakat mengingat pesantren pada dasarnya kekuatan sosial yang jumlahnya cukup besar. Secara umum akumulasi tata nilai dan kehidupan spiritual Islam di Pondok Pesantren pada dasarnya adalah lembaga 


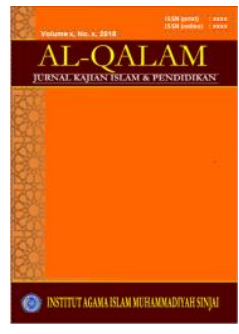

tafaqqu fiddin yang mengembang untuk meneruskan risalah Nabi Muhammad saw. Ekaligus melestarikan ajaran Islam. ${ }^{20}$

Pada dasarnya pondok pesantren merupakan lembaga pendidikan Islam yangdikelolah secara konvensional an dilaksanakan dengan sistem asrama (pondok) Dan kyai sebagai sentra utama masjid sebagai pusat lembaganya. Sejak awal p[ertumbuhannya, pesantren mempunyai bentuk yangberagam sehingga tidak ada suatu stndarisasi yang berlaku bagi semua pesantren. Namun demikian, proses pertumbuhan dan perkembangan pesantren tampak adanya polaumum, yang diambil dari makna peristilahan pesantren itu sendiri yang menunjukkan adanya suatu pola tertentu.

Pondok pesantren pada awalnya merupakan lembaga pendidikan dan pengajaran agama isla yang diberikan dengan cara non klasik (sistem pesantren) di mana seorang kyai mengajar santri-santri berdasarkan kitab - kitab yang ditulis dalam bahasa Arab oleh ulama-ulama besar dari abad pertengahan. Namun pada beberapa dasawarsa terakhir ini pesantren mengalami pergeseran yang dialami oleh pesantren. Beberapa indikator pergeseran tersebut adalah:

1. Kyai bukan lagi satu-satunya sumber belajar. Santri dapat belajardari beberapa sumber . 10 tahun terakhir ini banyak buku-buku pembaharuan pemikiran Islam yang ditulis dalam bahasa Indonesia baik para cendikiawan muslim Indonesia maupun terjemahan buku-buku yang ditulis oleh sarjanasarjana Islam di luar negeri yang dapat dibaca oleh santri-santri dan Uztads.

2. Dewasa ini hampir seluruh pesantren menyelenggran jenis pendidikan formal yaitu madrsah, sekolah umum dan perguruan tinggi

3. Seiring dengan pergeseran pola tersebut, santri membutuhkan ijazah dan penguasaan bidang keterampilan atau keahlian yang jelas yang dapat mengantarkan untuk menguasai lapangan kehidupan tertentu. Dalam era modern tidak cukup hanya berbekal dengan moral yang baik saja tetapi perlu dilengkapi modal keterampilan yang memadai yang relevan kebutuhan kerja kehidupan masa depan. Untuk itu dikalangan santri terdpat kecendrungan yang semakin kuat untuk mempelajari sains dan teknologi pada lembaga-lembaga pendidikan formal baik di madrasah maupun di sekolah umum untuk memperoleh keahlian dan keterampilan yang

20 M. Bahri Ghozali, Pesantren Berwawasan Lingkungan, (Jakarta: Prasasti, 2003), hlm. 1. 


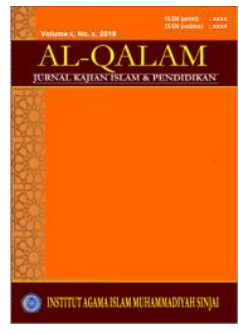

AL-QALAM

Jurnal Kajian Islam \& Pendidikan

Volume 06 No 012014

ISSN (print) : 1858-4152

ISSN (online) : -

Homepage : http://journal.iaimsinjai.ac.id/index.php/al-qalam

dimaksud tetapi mereka juga ingin tetap belajar di suasana pesantren untuk mendalami agama.

2. Manajemen Pembelajaran di Sekolah dan Madrasah

Keberadaan sekolah dan madrasah seperti sekarang ini merupakan akumulasi beraneka macam budaya dan tradisi pendidikan yang berkembang di Indonesia. Mulai dari tradisi prasejarah atau tradisi asli, tradisi Hindu Budha, tradisi Islam dan tradisi barat modern. Oleh sebab itu, sekolah dan madrasah telah menjadi salah satu wujud entitas budaya bangsa Indonesia yang telah menjalani proses sosialisasi yang relative intensif dan dalam waktu yang cukup panjang itu telah memainkan peran tersendiri dalam panging penmbentukan peradaban bangsa.

Dilihat dari pengelolaannya, pendidikan sistem madrasah ini memungkinkan cara pembelajaran secara klasikal. Pengelolaan sistem madrasah juga memungkinkan adanya pengelompokan pelajaran-pelajaran tentang pengetahuan Islam yang penyampaiannya dilakukan secara bertingkat-tingkat dengan memperhitungkan rentang waktu yang dibutuhkan, sehingga secara teknis, sistem madrasah berusaha mengorganisasikan kegiatan kependidikannya dengan sistem kelas-kelas berjenjang dengan wkatu yang diperlukan untuk menyelesaikan pelajaran yang sudah dipolakan. Sedangkan sistem yang diterapkan di bangku sekolah cukup tergolong modern dibandingkan di madrasah, tapi yang terkadang menjadi persamaan metode yang dipakai oleh para tenaga pengajar.

Dengan demikian agar mutu pembelajaran di lembaga pendidikan baik sekolah, maupun madrasah, dapat dikelolah dengan baik, maka ada beberapa langkah yang harus dilaksanakan oleh para pelaku di lembaga pendidikan tersebut, antara lain:

\section{Perencanaan}

Perencanaan adalah proses penentuan tujuan atau sasaran yang hendak dicapai dan menetapkan jalan dan sumber yang diperlukan untuk mencapai tujuan itu seefisien dan seefektif mungkin. Dalam setiap perencanaan terdapat tiga kegiatan yang meskipun dapat dibedakan, tetapi tidak dapat dipisahkan antara satu dengan yang lainnya, dalam proses perencanaan yaitu:

a. Perumusan tujuan yang ingin dicapai

b. Pemilihan program untuk mencapai tujuan tersebut. 
c. Identifikasi dan pengarahan sumber yang jumlahnya selalu terbatas.

2. Pengorganisasian

Pengorganisasian merupakan proses membagi kerja ke dalam tugas-tugas itu kepada orang yang sesuai dengan kemampuannya, dan mengalokasikan sumber daya, serta mengkoordinasikannya dalam rangka efektivitas pencapaian tujuan organisasinya.

3.Pelaksanaan

Pemimpin pada hakikatnya adalah seorang yang mempunyai kemampuan untuk mempengaruhi perilaku orang lain di dalam dengan menggunakan kekuasaan. Kekuasaan adalah kemampuan untuk mengarahkan dan mempengaruhi bawahan, sehubungan dengan tugas-tugaas yang harus dilaksanakannya. Dalam lembaga pendidikan Islam yang dimaksud pemimpin adalah Kyai atau Ustad dalam pondok pesantren, guru dalam madrasah dan sekolah.

\section{Evaluasi}

Evaluasi diperlukan untuk melihat sejauhmana hasil tercapai. Evaluasi merupakan proses dasar yang secara esensial tetap diperlukan bagaimanapun rumit dan luasnya suatu organisasi. Proses dasar terdiri dari tiga tahap yaitu:

a. Menetapkan standar pelaksanaan

b. Pengukuran pelaksanaan pekerjaan

c. Menentukan kesenjangan antara pelaksanaan dengan standard an terencana.

\section{KESIMPULAN}

Dari pembahasan di atas dapat disimpulkan bahwa, inti proses pendidikan adalah pembelajaran, dan inilah aktifitas rutin yang dilakukan oleh guru maupun ustadz atau kyai. Proses pembelajaran dapat didesain oleh sedemikian rupa. Idealnya kegiatan untuk siswa yang pandai harus berbeda dengan untuk siswa yang sedang, atau kurang. Walaupun untuk memahami jenis konsep yang sama karena setiap peserta didik mempunyai keunikan masing-masing. Hal ini menunjukkan bahwa pemahaman terhadap pendekatan, metode dan teknik pengelolaan pembelajaran tidak bisa diabaikan. Oleh karena itu agar proses belajar mengajar yang dilakukan berjalan lancar dan dapat menciptakan iklim yang kondusif dimana peserta didik merasa nyaman dan tidak tertekan dalam 


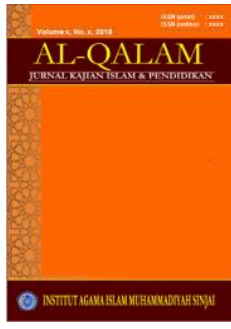

menerima pelajaran, maka dibutuhkan manajemen dalam mengelola pembelajaran tersebut.

Manajemen pembelajaran selain diawali dengan dengan perencanaan yang baik, serta didukung komunikasi yang baik, juga harus didukung pengembangan strategis yang mampu membelajarkan siswa. Karena manajemen pembelajaran ,merupakan suatu proses penyelenggaraan intraksi peserta didik, pendidikk dan sumber pada suatu lingkungan belajar.

\section{DAFTAR PUSTAKA}

Amin Haedarai, dkk. Masa Depan Pesantren: dalam Tantangan Modernitas dan Tantangan Koplksitas Global, Jakarta: IRD Press Jakarta, 2004.

Bahri Ghozali.M, Pesantren Berwawasan Lingkungan, Jakarta: Prasasti, 2003.

Henri Simamora, Manajemen Sumber Daya Manusia, Yogyakarta: Bagian Penerbitan STIE YKPN, 2004.

Husaini Usman, Managemen Teori, Praktik dan Riset Pendidikan, Jakarta: Bumi Aksara,2006.

Manulang. M, Dasar-Dasar Manajemen, (Yogyakarta: Gadja Mada University Press, 2009.

Miftah Toha, Perilaku Organisasi, Konsep Dasar dan Aplikasi, Jakarta: Raja Grafindo, 2006.

Mulyasa E, Implementasi Kurikulum 2004 Panduan Pembelajaran KBK, Bandung: Remaja Rosda Karya, 2004.Safruddin dan Irwan Nasution, Manajemen Pembelajaran, Jakarta: Quantum Teaching, 2005.

Suharsimi Arikunto, Pengelolaan Kelas dan Siswa Sebuah Pendekatan Evaluatve, Jakarta: Raja Grafindo Persada, 1996.

Syaiful Sagala, Konsep dan makna Pembelajaran; untuk membentuk, memecahkan problematika belajar dan mengajar, Bandung: Alfabeta, 2009.

Suwardi, Manajemen Pembelajaran; Menciptakan Guru Kreatif dan Berkompetensi, Jogjakarta: STAIN Salatiga Press, 2007.

Tohirin, Psikologi Pembelajaran Pendidikan Agama Islam Berbasis Integrasi dan Kompetisi, Jakarta: Raja Grafindo Persada, 2000. 


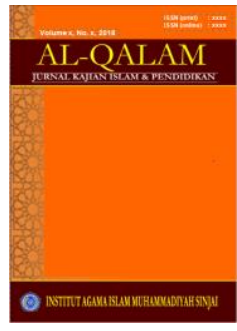

AL-QALAM

Jurnal Kajian Islam \& Pendidikan

Volume 06 No 012014

ISSN (print) : 1858-4152

ISSN (online) : -

Homepage : http://journal.iaimsinjai.ac.id/index.php/al-qalam

Wina Sanjaya, Strategi Pembelajaran Berorientasi Standar Proses Pendidikan, Jakarta: Kencana, 2011.

Wina Sanjaya, Strategi Pembelajaran, Jakarta: Kencana, 2006.

UU SIKDIKNAS, Peraturan dan Pelaksanaannya, Jakarta: Sinar Grafika, 1991.

Zainal Arifin, Evaluasi Pembelajaran: Prinsip Teknik, Prosedur, Bandung: Remaja Rosda Karya, 2009. 